\title{
Cytomegalovirus Encephalitis Under Fingolimod Mimicking Progressive Multifocal Leukoencephalopathy?
}

Dierk Oel, MD, Kinga Rigler-Hohenwarter, MD, Johannes Trenkler, MD, and Raffi Topakian, MD

Neurol Neuroimmunol Neuroinflamm 2021;8:e996. doi:10.1212/NXI.0000000000000996

\author{
Correspondence \\ Dr. Topakian \\ raffi.topakian@hotmail.com
}

Fingolimod, a sphingosine-1-phosphate receptor modulator approved for the treatment of relapsing multiple sclerosis (RMS), may rarely lead to CNS infections through reactivation of herpesviruses or JC virus (JCV), the cause of progressive multifocal leukoencephalopathy (PML). ${ }^{1,2}$ The authors present a patient with clinical and MRI features suggestive of PML under fingolimod. Repeat PCR testing for JCV DNA in CSF was negative, whereas cytomegalovirus (CMV) DNA was found positive. Treatment with ganciclovir was followed by clinical and MRI improvement.

\section{Case Vignette}

A 37-year-old man was diagnosed with clinically isolated syndrome after developing cervical myelitis with MRI showing few supratentorial lesions and CSF positive for oligoclonal bands. He subsequently converted to RMS with recurrent relapses of spinal symptoms. After 4 years of treatment with interferon-beta $1 \mathrm{~b}$, he was switched to fingolimod because of intolerable side effects.

Two years after starting fingolimod, routine MRI showed small new bilateral occipital lesions and one left frontal lesion (figure, "m13"), which were clinically asymptomatic and felt to be because of RMS, as up to then there had not been any reports on PML under fingolimod without previous natalizumab therapy. Another relapse with spinal symptoms responded well to IV methylprednisolone. Eleven months after the last routine MRI, he developed left inferior homonymous quadrantanopia. Serial MRIs showed progressive enlargement of the right occipital lesion, again without restricted diffusion or contrast enhancement (figure, "m24" and "m26"). Other lesions remained stable. PML was suspected. Serum JCV antibody index measured 10 weeks after symptom onset was positive (2.89; STRATIFY JCV DxSelect; Unilabs, Copenhagen, Denmark). Fingolimod was stopped. He never had grade 4 lymphopenia $<0.2 \mathrm{G} / \mathrm{L}$.

Four CSF examinations showed normal cell counts (up to $3 / \mu \mathrm{L}$ ) and slightly raised protein (up to $48 \mathrm{mg} / \mathrm{dL}$ ). Repeat PCR tests for JCV DNA in CSF at local laboratories and (once) the NIH reference laboratory (Bethesda, $\mathrm{MD}$ ) were negative. Differential diagnoses such as varicella zoster virus (VZV) encephalitis and lymphoma were discarded because of negative PCR in CSF and neuroimaging characteristics. However, serum was positive for anti-CMV IgG, and CSF was positive for CMV DNA on PCR testing (with CMV viral load $<1,250$ copies/mL), introducing the possibility of atypical CMV encephalitis (CMVE). The patient refrained from undergoing brain biopsy and instead opted for antiviral treatment. After 3 weeks of IV ganciclovir ( $5 \mathrm{mg} / \mathrm{kg}$ every 12 hours), there was evidence of clinical and MRI improvement (figure, "m30"), and PCR testing for CMV DNA in CSF had turned negative. Four years later, the patient had remained stable (EDSS 3.5) and relapse-free without restarting disease-modifying therapy, with only one small additional periventricular MS-type lesion on MRI follow-up.

From the Department of Neurology (D.O., R.T.), Academic Teaching Hospital Wels-Grieskirchen; Institute of Hygiene and Microbiology (K.R.-H.), Academic Teaching Hospital WelsGrieskirchen, Wels; and Institute of Neuroradiology (I.T.), Neuromed Campus, Kepler University Hospital, Linz, Austria.

Go to Neurology.org/NN for full disclosures. Funding information is provided at the end of the article.

The Article Processing Charge was funded by the authors.

This is an open access article distributed under the terms of the Creative Commons Attribution-NonCommercial-NoDerivatives License 4.0 (CC BY-NC-ND), which permits downloading and sharing the work provided it is properly cited. The work cannot be changed in any way or used commercially without permission from the journal. 


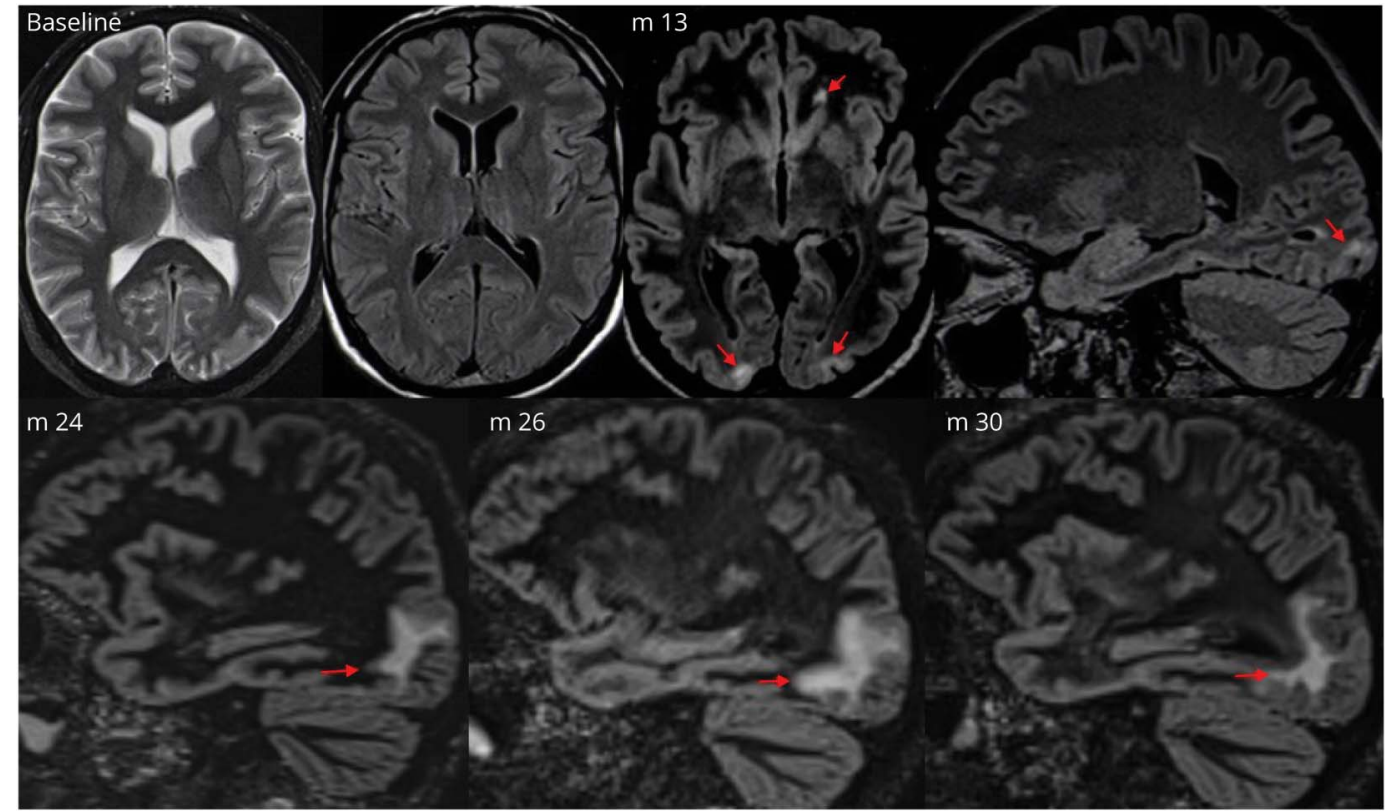

"Baseline" (T2 axial and fluid-attenuated inversion recovery [FLAIR] axial): MRI before starting fingolimod shows no substantial lesions in the left frontal and both occipital regions; "m13" (FLAIR space, axial and FLAIR space, sagittal): Routine MRI 13 months after starting fingolimod shows new (asymptomatic) bilateral occipital hyperintense lesions at the gray matter-white matter junction and one new left frontal lesion; "m24" (FLAIR space, sagittal): MRI 24 months after starting fingolimod shows progression of the right occipital lesion; "m26" (FLAIR space, sagittal): MRI 26 months after starting fingolimod shows further progression of the right occipital lesion; "m30" (FLAIR space, sagittal): MRI 30 months after starting fingolimod shows regression of the right occipital lesion after discontinuation of fingolimod and treatment with IV ganciclovir over 3 weeks.

\section{Discussion}

This patient's clinical and MRI course made PML under fingolimod the most likely diagnosis. The insidious, at first asymptomatic development of high-signal intensity cerebral gray matter-white matter junction lesions on T2 and FLAIR images is in keeping with classic PML. ${ }^{3}$ Recent data suggest that age of $>45$ years and treatment for $>2$ years may increase the risk of PML under fingolimod. ${ }^{2}$ The patient had a positive serum JCV antibody index. After repeat negative testing for JCV DNA in CSF, including testing in the NIH reference laboratory, the patient was classified as "possible PML" according to consensus criteria. ${ }^{3}$

Further workup revealed CMV DNA in CSF. This finding did not resolve the diagnostic dilemma as some patients with suspected PML may have difficult-to-interpret presence of DNA of herpesviruses in CSF. ${ }^{4}$ PCR testing for CMV DNA has high sensitivity and specificity. However, low quantities of viral copies may not lead to symptoms. In our patient, we cannot exclude the possibility of a limited form of PML with concomitant asymptomatic CMV reactivation under fingolimod.

Our knowledge of CMVE heavily relies on the literature on AIDS. CMVE complicating AIDS usually presents with encephalopathy and predominant cognitive and behavioral symptoms, and imaging abnormalities in the periventricular parenchyma and meninges. CSF cell counts often are normal. ${ }^{5}$ However, extrapolating these findings to patients without AIDS may not be warranted.

By contrast, several facts point toward a role of CMV in the development of encephalitis in our patient: (1) CMVE has been listed as one of the top differential diagnoses of $\mathrm{PML}^{6}$; (2) CNS infections with other herpesviruses such as VZV under fingolimod have been reported; (3) repeat PCR tests of JCV-DNA in CSF were negative throughout; and (4) treatment with ganciclovir was followed by clinical and MRI improvement, and a negative PCR for CMV DNA in CSF.

In the absence of brain biopsy, additional laboratory testing might have been useful. A rise of JCV antibody titers on serial measurement may underpin the diagnosis of PML. However, at the time of the patient's presentation, this had not been a consideration in a consensus algorithm for diagnosing PML. ${ }^{3}$ Although low anti-JCV antibodies in serum may render PML unlikely, an elevated CSF:serum anti-JCV antibody index would support the diagnosis. ${ }^{7}$ Importantly, recent evidence from natalizumab-associated PML cases suggests that small PML lesion volume may be associated with (false) negative JCV PCR in CSF. ${ }^{8}$ The final verdict on the diagnosis in this case remains impossible without neuropathologic data.

In conclusion, this case raises awareness (1) of the difficulties in attributing a PML-like lesion without brain biopsy in the 
context of repeat negative PCR tests of JCV-DNA in CSF and (2) to consider CMVE in the differential diagnosis of PML under fingolimod.

\section{Study Funding}

The authors report no targeted funding.

\section{Disclosure}

The authors report no disclosures relevant to the article. Go to Neurology.org/NN for full disclosures.

\section{Publication History}

Received by Neurology: Neuroimmunology \& Neuroinflammation July 5, 2020. Accepted in final form March 16, 2021.

\section{Appendix Authors}

\begin{tabular}{lll}
\hline Name & Location & Contribution \\
\hline Dierk Oel, MD & $\begin{array}{l}\text { Academic Teaching } \\
\text { Hospital Wels- } \\
\text { Grieskirchen, Wels, } \\
\text { Austria }\end{array}$ & $\begin{array}{l}\text { Major role in the } \\
\text { acquisition of data; } \\
\text { analyzed the data; revised } \\
\text { the manuscript for } \\
\text { intellectual content }\end{array}$ \\
\hline $\begin{array}{l}\text { Kinga Rigler- } \\
\text { Hohenwarter, } \\
\text { MD }\end{array}$ & $\begin{array}{l}\text { Academic Teaching } \\
\text { Hospital Wels- } \\
\text { Grieskirchen, Wels, Austria }\end{array}$ & $\begin{array}{l}\text { Interpreted the data; } \\
\text { revised the manuscript for } \\
\text { intellectual content }\end{array}$ \\
\hline
\end{tabular}

Appendix (continued)

\begin{tabular}{lll}
\hline Name & Location & Contribution \\
\hline $\begin{array}{l}\text { Johannes } \\
\text { Trenkler, MD }\end{array}$ & $\begin{array}{l}\text { Kepler University } \\
\text { Hospital, Linz, Austria }\end{array}$ & $\begin{array}{l}\text { Interpreted the data; } \\
\text { revised the manuscript for } \\
\text { intellectual content }\end{array}$ \\
\hline $\begin{array}{l}\text { Raffi } \\
\text { Topakian, MD }\end{array}$ & $\begin{array}{l}\text { Academic Teaching } \\
\text { Hospital Wels- } \\
\text { Grieskirchen, Wels, } \\
\text { Austria }\end{array}$ & $\begin{array}{l}\text { Designed and } \\
\text { conceptualized study; } \\
\text { analyzed the data; drafted } \\
\text { the manuscript for } \\
\text { intellectual content }\end{array}$ \\
\hline
\end{tabular}

\section{References}

1. Arvin AM, Wolinsky JS, Kappos L, et al. Varicella-zoster virus infections in patients treated with fingolimod: risk assessment and consensus recommendations for management. JAMA Neurol. 2015;72:31-39.

2. Berger JR, Cree BA, Greenberg B, et al. Progressive multifocal leukoencephalopathy after fingolimod treatment. Neurology. 2018;90:e1815-e1821.

3. Berger JR, Aksamit AJ, Clifford DB, et al. PML diagnostic criteria: consensus statement from the AAN Neuroinfectious Disease Section. Neurology. 2013;80: 1430-1438.

4. Nakamichi K, Inoue N, Shimokawa T, Kurane I, Lim CK, Saijo M. Detection of human herpesviruses in the cerebrospinal fluid from patients diagnosed with or suspected of having progressive multifocal leukoencephalopathy. BMC Neurol. 2013;13:200.

5. Holland NR, Power C, Mathews VP, Glass JD, Forman M, McArthur JC. Cytomegalovirus encephalitis in acquired immunodeficiency syndrome (AIDS). Neurology. 1994;44:507-514.

6. Osborn AG, Digre KB. Imaging in Neurology, 1st ed. Elsevier, Inc; 2016.

7. Kuhle J, Gosert R, Bühler R, et al. Management and outcome of CSF-JC virus PCR-negative PML in a natalizumab-treated patient with MS. Neurology. 2011;77:2010-2016.

8. Wijburg MT, Kleerekooper I, Lissenberg-Witte BI, et al. Association of progressive multifocal leukoencephalopathy lesion volume with JC virus polymerase chain reaction results in cerebrospinal fluid of natalizumab-treated patients with multiple sclerosis. JAMA Neurol. 2018;75:827-833. 


\section{Neurology ${ }^{\oplus}$ \\ Neuroimmunology \& Neuroinflammation}

Cytomegalovirus Encephalitis Under Fingolimod Mimicking Progressive Multifocal Leukoencephalopathy?

Dierk Oel, Kinga Rigler-Hohenwarter, Johannes Trenkler, et al.

Neurol Neuroimmunol Neuroinflamm 2021;8;

DOI 10.1212/NXI.0000000000000996

This information is current as of April 9, 2021

Neurol Neuroimmunol Neuroinflamm is an official journal of the American Academy of Neurology.

Published since April 2014, it is an open-access, online-only, continuous publication journal. Copyright

Copyright $\odot 2021$ The Author(s). Published by Wolters Kluwer Health, Inc. on behalf of the American

Academy of Neurology.. All rights reserved. Online ISSN: 2332-7812.

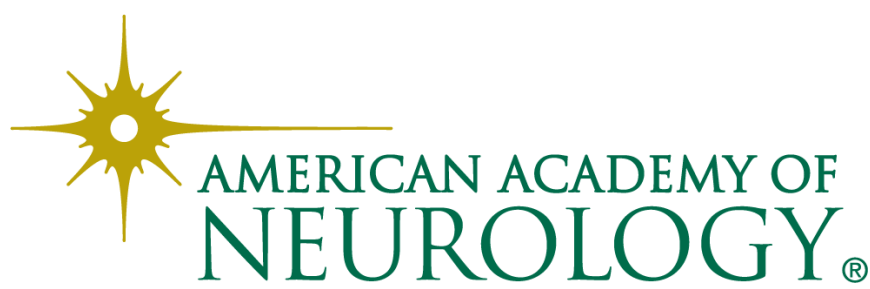




\section{Updated Information \& Services}

References

Subspecialty Collections

Permissions \& Licensing

\section{Reprints}

including high resolution figures, can be found at:

http://nn.neurology.org/content/8/4/e996.full.html

This article cites 7 articles, 0 of which you can access for free at: http://nn.neurology.org/content/8/4/e996.full.html\#\#ref-list-1

This article, along with others on similar topics, appears in the following collection(s):

All Demyelinating disease (CNS)

http://nn.neurology.org//cgi/collection/all_demyelinating_disease_cns Encephalitis

http://nn.neurology.org//cgi/collection/encephalitis

\section{MRI}

http://nn.neurology.org//cgi/collection/mri

Multiple sclerosis

http://nn.neurology.org//cgi/collection/multiple_sclerosis

\section{Viral infections}

http://nn.neurology.org//cgi/collection/viral_infections

Information about reproducing this article in parts (figures,tables) or in its entirety can be found online at:

http://nn.neurology.org/misc/about.xhtml\#permissions

Information about ordering reprints can be found online: http://nn.neurology.org/misc/addir.xhtml\#reprintsus

Neurol Neuroimmunol Neuroinflamm is an official journal of the American Academy of Neurology.

Published since April 2014, it is an open-access, online-only, continuous publication journal. Copyright

Copyright $\odot 2021$ The Author(s). Published by Wolters Kluwer Health, Inc. on behalf of the American Academy of Neurology.. All rights reserved. Online ISSN: 2332-7812.

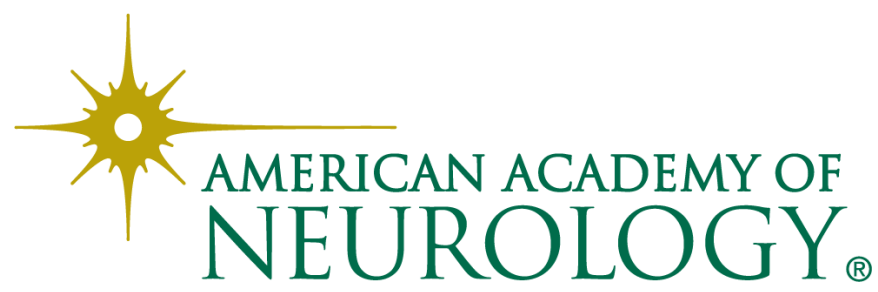

